\title{
Bloody revolutions, fascist dreams, anarchy and peace: Crass, Rondos and the politics of punk, 1977-84
}

Article

Accepted Version

Worley, M. and Lohman, K. (2018) Bloody revolutions, fascist dreams, anarchy and peace: Crass, Rondos and the politics of punk, 1977-84. Britain and the World: Historical Journal of the British Scholar Society, 11 (1). pp. 51-74. ISSN 2043-8567 doi: https://doi.org/10.3366/brw.2018.0287 Available at https://centaur.reading.ac.uk/73452/

It is advisable to refer to the publisher's version if you intend to cite from the work. See Guidance on citing.

To link to this article DOI: http://dx.doi.org/10.3366/brw.2018.0287

Publisher: University of Edinburgh Press

All outputs in CentAUR are protected by Intellectual Property Rights law, including copyright law. Copyright and IPR is retained by the creators or other copyright holders. Terms and conditions for use of this material are defined in the End User Agreement.

www.reading.ac.uk/centaur 
Central Archive at the University of Reading

Reading's research outputs online 
Bloody Revolutions, Fascist Dreams, Anarchy and Peace: Crass, Rondos and the Politics of

\section{Punk, 1977-84}

\section{Kirsty Lohman and Matthew Worley}

Punk and politics have long made for an unstable mix. Almost from the outset, the Sex Pistols stirred political imaginations, be it in journalists looking to find a cultural response to the fraught socio-economic conditions of the mid-1970s or eager activists searching for youthful insurrection. ${ }^{1}$ In the UK, far more than America, punk's emergence came decorated with political signifiers. A curious blend of anarchy, swastikas and situationist references comprised part of Vivienne Westwood and Malcolm McLaren's semiotic arsenal. Social realism, too, brokered The Clash's aim of making people 'do things for themselves, think for themselves and stand up for their rights'. ${ }^{2}$ Their 'anti-fascist, anti-violence, anti-racist and pro-creative' stance provided inspiration for many and helped cement punk's link to causes such as Rock Against Racism (RAR). ${ }^{3}$ Not everyone ascribed to such interpretation. Early British punk was often more snotty insolence than incipient political consciousness; overtly political connotations were routinely denied. ${ }^{4}$ Nevertheless, the style, sound and aesthetic of punk came loaded with potential meaning that took it beyond the realm of 'just' music or fashion. Punk's influence spread around the world and for many did become a medium for

\footnotetext{
${ }^{1}$ Caroline Coon, 'Punk Rock: Rebels Against the System', Melody Maker, 7 August 1976, pp. 24-5; Dave Marsh, 'Dole Queue Rock', New Society, 20 January 1977, pp. 112-14; Matthew Worley, 'Shot By Both Sides: Punk, Politics and the End of "Consensus"', Contemporary British History, 26, no. 3 (2012), 333-54.

2 Steve Walsh, 'The Very Angry Clash', Sniffin' Glue, no. 4, 1976, pp. 3-6.

${ }^{3}$ Barry Miles, 'Eighteen Flight Rock and the Sound of the Westway', NME, 11 December 1976, p. 14. For RAR, see Ian Goodyer, Crisis Music: The Cultural Politics of Rock Against Racism (Manchester, 2009); Daniel Rachel, Walls Come Tumbling Down: The Music and Politics of Rock Against Racism, 2-Tone and Red Wedge (London, 2016); Dave Renton, When We Touched the Sky: The Anti-Nazi League, 1977-81 (Cheltenham, 2006); David Widgery, Beating Time: Riot ' $n$ ' Race ' $n$ ' Rock ' $n$ ' Roll (London, 1986).

${ }^{4}$ See, for example, Allan Jones, 'Rotten!', Melody Maker, 4 June 1977, pp. 8-9 and 52.
} 
political expression, providing a modus operandi for radical ideas and innovative cultural practice. In the Netherlands, for example, as we shall see, the political strands of British punk proved important, even as Dutch punk followed its own trajectory through the country's unique socio-cultural and political environment.

Two groups that exemplified such an approach were Crass and Rondos. Crass formed in 1977, a band that grew into a collective around the initial nucleus of Penny Rimbaud (Jeremy Ratter) and Steve Ignorant (Steve Williams). ${ }^{5}$ They were based at Dial House in Epping Forest on the edge of London's sprawl, an old farmhouse that Rimbaud and others had renovated from the late 1960s. Notably, the group comprised a range of ages, genders, class and backgrounds. ${ }^{6}$ Before 1977, moreover, most members had experimented with music and the arts, working through the pre-punk counterculture in search of creative alternatives to mainstream social structures and expectations. Accordingly, perhaps, Crass proved able to cultivate a unique sound, image and worldview that sought to transform punk's rhetorical anarchy into a viable political and cultural opposition. Across a series of EPs, LPs and 7-inch singles, the band issued aural broadsides against everything from Christianity ('Reality Asylum') and the inequities of 'the system' ('Big A Little A') to patriarchy (Penis Envy) and the rigid orthodoxies of leftist politics ('Bloody Revolutions'). Where the Sex Pistols embraced the liberatory thrill of chaos, Crass devised a design for life best summarised in their slogan 'there is no authority but yourself'. In other words, Crass

\footnotetext{
${ }^{5}$ The core Crass line up comprised Joy de Vivre (vocals), Mick Duffield (films), Phil Free (guitar), Steve Ignorant (vocals), Eve Libertine (vocals), Andy Palmer (guitar), Penny Rimbaud (drums) Gee Vaucher (artwork, vocals) and Pete Wright (bass). To date, two autobiographies exist: Penny Rimbaud, Shibboleth: My Revolting Life (Edinburgh, 1998); Steve Ignorant with Steve Pottinger, The Rest is Propaganda (London, 2010).

${ }^{6}$ George Berger, The Story of Crass (London, 2006); Peter Webb, 'Crass, Subculture and Class: The Milieu Culture of DIY Punk', in Subcultures Network (eds), Fight Back: Punk, Politics and Resistance (Manchester, 2015), pp. 99-116. For example, Ignorant was a still a teenager in 1977, an erstwhile skinhead and Bowie freak from working-class Dagenham. Rimbaud, by contrast, was 34 and privately educated.
} 
took punk seriously: they recognised within it an extension of pre-existing countercultures and sought to mould its associated values of autonomy and provocation into a potent critique. A legion of bands and artists emerged in their wake, holding firm to the punk banner before Crass finally broke up in 1984, buckling under internal strains but simultaneously complementing the Orwellian countdown that had loomed over their activities from the outset. ${ }^{7}$ The catalogue numbers on their records - from The Feeding of the Five Thousand's '621984' to 'You're Already Dead's '1984' - ticked off the years until the imagined jackboot stamping on a human face forever was revealed in fact to be a Tory court shoe. $^{8}$

In terms of music, Crass tended towards the harsh and discordant. They quickly developed a recognisable sound based on Rimbaud's skitterry, almost military-style drumming and an incessant buzz of guitar noise that buried standard chords beneath feedback, amp hum and speed. Songs bled into one another as the band's politicallycharged lyrics spewed forth from the mouths of Ignorant, Eve Libertine (Bronwyn Lloyd Jones), Joy de Vivre (Joy Haney) and Pete Wright, each song seemingly written to a specific brief or focused on a particular target. Authority figures were besmirched, institutions undermined and punk's own cultural development reviewed to expose any compromise/contradiction. Indeed, Crass' songs were intended to incite and confront. Early records and texts offered proactive alternatives to prevailing socio-political structures and ideas, before the Falklands War (1982) began a more reactive approach, the band

\footnotetext{
7 'Crass Interview', Anathema, no. 1 (1982), pp. 11-14.

8 Richard Cross, 'The Hippies Now Wear Black: Crass and the Anarcho-Punk Movement, 1977-84', Socialist History, no. 26 (2004), 25-44; Alastair Gordon, Throwing Out the Punk Rock Baby With the Dirty Bath Water: Crass and Punk Rock, A Critical Appraisal (Nottingham: 1996); George McKay, Senseless Acts of Beauty: Currents of Resistance since the Sixties (London, 1996).
} 
commenting on contemporary events as they occurred whilst endeavouring to locate them within a wider analysis of dominant ideological systems. As this suggests, the various 'spaces' provided by popular music culture - and, by extension, punk - were utilised to disseminate information and facilitate dissent. Crass' records came wrapped in black-andwhite foldout sleeves designed by Gee Vaucher to give visual complement to their content. Opened up, they comprised lyric sheets, essays and points of contact. Crass gigs, most of which were benefits for an array of progressive causes, served both as a good night out and a forum for political engagement. Film, posters, printouts and pamphlets accompanied the music. And though the band's uniform-image of plain black clothes was designed to reject the idea of popstar-personality or punk-as-fashion, it simultaneously gave Crass a collective identity that found favour across an expanding audience. To look back at the thenimportant 'independent charts' of the early 1980s is to see, more often than not, Crass and Crass-inspired bands jostling for position.

Rondos formed a little later than Crass, in March 1978. The band emerged from the KunstKollectief Dubio (KK Dubio), a group of students studying at Rotterdam's art academy. Several members of KK Dubio played in Rondos at some point, but the line-up soon settled to become: Johannes van de Weert (singer), Allie van Altena and Maarten van Gent (guitarists), Frank Seltenrijch (bass) and Wim ter Weele (drums). Like Crass, the band - as part of a collective - lived and worked together, fixing up a derelict building south of the city centre, called the Huize Schoonderloo, to provide living quarters, art studios, offices and printing rooms, as well as rehearsal space they made available to other Rotterdam punks. The house thereby became the city punks' spiritual home, different but similar to the role played by Dial House in Britain among those who eventually became known as anarcho- 
punks.

Rondos' punk 'career' was also significantly shorter than Crass'; they broke up in September 1980. However, their legacy in The Netherlands is without doubt. ${ }^{9}$ The band helped build and lent support to punk networks in Rotterdam and beyond, setting up a Red Rock Collective with three other bands to provide a ready-to-go gig line up and shared equipment. At Huize Schoonderloo, Dutch punks could access practical tools and advice on how to do-it-yourself (DIY). KK Dubio further ran Raket printing and distribution for almost a decade. And while the Rondos' spindly-but-harshly stripped-down music quickly found an audience, it was the messages they conveyed that bore the greatest influence. Known (variously) as 'bloody heavy' Maoists ${ }^{10}$, communists and sometimes misread as anarchists ${ }^{11}$, Rondos avoided too close an allegiance with any political label. Across their music, aesthetic and fanzines may be found posters of Mao (included with their 1980 Which Side Will You Be On? EP); a hammer-and-sickle adorned Dutch flag used for a backdrop at gigs; songs and essays extolling the virtues of communism; and 'Anarchy' on the album Red Attack (1980). Simultaneously, the band worked to counter such labels. ${ }^{12}$ Essays in their Raket fanzine attacked those who called them Maoists ${ }^{13}$ and explained how the band held sympathy for anarchist ideas but did not identify as such. ${ }^{14}$ In the liner notes to their twentiethanniversary box set release, A Black \& White Statement (2009), Rondos presented their

\footnotetext{
9 Jerry Goossens and Jeroen Vedder, Het Gejuich Was Massaal: Punk in Nederland 1976-1982 (Amsterdam, 1996); Leonor Jonker, No Future Nu: Punk in Nederland 1977-2012 (Amsterdam, 2012).

${ }^{10}$ Particularly in the UK, where memory of the band is shaped by accounts from Crass members. See, for example, Phil Free, in Berger, The Story of Crass, p. 146.

${ }^{11}$ Rimbaud, Shibboleth, p. 118.

${ }^{12}$ This can be read as part of wider punk practices to 'evade' definition, see Yngvar B. Steinholt, 'Punk is Punk but By No Means Punk: Definition, Genre Evasion and the Quest for an Authentic Voice in Contemporary Russia,' Punk \& Post-Punk, 1, no. 3 (2012), 267-284.

${ }^{13}$ Rondos, 'Antwoord aan: Henno Eggenkamp', Raket, no. 8 (January 1980), n.p.

${ }^{14}$ Rondos, 'Over Anarchism en Kommunisme', Raket, no. 7 (December 1979), n.p.
} 
communism as half-provocation and 'half-serious' political statement. ${ }^{15}$ The overriding message, both of Rondos and the KK Dubio, was: 'think [critically] for yourself'. Thus, Raket had a no censorship policy, committing to publish all and anything that was submitted to it. The idea was to foster debate among punks who held a variety of political opinions. Come 1980 and the band split on account of their self-perceived failure to lead an effective political discussion. Punk had become 'subcultural', they reasoned; a site of uncritical fandom ${ }^{16}$ and hedonism based around drugs and alcohol. ${ }^{17}$

This article examines the way Crass and Rondos constructed and communicated their politics. In particular, it focuses on the bands' relationship to the fanzines that flowered as a result of punk's emphasis on DIY. ${ }^{18}$ While recognising continuities across their respective approaches, it also notes certain tensions; tensions that were brought into sharp relief when the two bands were scheduled to appear together - with Poison Girls - at London's Conway Hall on 8 September 1979. The objective is to offer both a history from below, emphasising how punk's politics were cultivated and understood by those who forged and participated in the culture, and a comparative study that considers how punk's political meaning transmitted across geographical boundaries and evolved within differing cultural-political contexts. By using fanzines, it hopes to capture something of the interaction that took place between bands and 'fans' in determining punk's cultural and political import. It further hopes to capture punk's contested politics in the process of

\footnotetext{
${ }^{15}$ Rondos, 'A Black \& White Statement: Biografie', liner notes to Rondos, A Black \& White Statement (King Kong, 2009), p 59.

16 Jonker, No Future $\mathrm{Nu}$, n.p.

${ }^{17}$ Rondos, 'A Black \& White Statement: Biografie', pp. 79-80.

18 Matthew Worley, 'Punk, Politics and British (fan)zines, 1976-84: "While the world was dying, did you wonder why?"', History Workshop Journal, no. 79 (2015), 76-106; Teal Triggs, Fanzines (London, 2010); idem, 'Scissors and Glue: Punk Fanzines and the Creation of a DIY Aesthetic', Journal of Design History, 19, no. 1 (2006), 69-83.
} 
formation, examining how meanings and practices were presented, discussed and negotiated.

To date, most academic - not to mention most journalistic and popular - accounts of punk have eschewed historical analysis. From Dick Hebdige's semiotics to Nick Crossley's network theory, from Helen Reddington's recovery of 'the lost women of rock' to the copious - if endlessly readable - oral histories and punk-related autobiographies, the emphasis has tended to be on applying theoretical paradigms or interweaving subjective/personalised reminiscences to build an overarching narrative. ${ }^{19}$ Important sociological investigations and cultural studies abound, both in relation to punk and punkinformed cultures such as goth. ${ }^{20}$ But these are typically concerned with understanding contemporary experience. Certainly, the erstwhile Centre for Contemporary Cultural Studies (CCCS) rarely added a historical dimension to its ground-breaking research. ${ }^{21}$ As for politics, these are often applied or denied, depending on the author. ${ }^{22}$

There are notable exceptions. Simon Reynolds, Jon Savage and David Wilkinson have each shown a keen historical eye to locate their own particular readings of punk and postpunk politics; Matthew Worley has produced a number of works viewing the politics of punk-related cultures through a historical lens. ${ }^{23}$ Equally, the work of Laura Cofield, Lucy

\footnotetext{
${ }^{19}$ Dick Hebdige, Subculture: The Meaning of Style (London, 1979); Nick Crossley, Networks of Style, Sound and Subversion: The Punk and Post-Punk Worlds of Manchester, London, Liverpool and Sheffield, 1975-80 (Manchester, 2015); Helen Reddington, The Lost Women of Rock Music: Female Musicians of the Punk Era (Aldershot, 2007); John Robb, Punk Rock: An Oral History (London, 2006).

${ }^{20}$ For example, Paul Hodkinson, Goth: Identity, Style and Subculture (Oxford, 2002); David Muggleton, Inside Subculture: The Postmodern Meaning of Style (Oxford, 2000).

${ }^{21}$ For some discussion, see John Clarke et al., 'Subcultures, Cultures and Class: A Theoretical Overview', in Stuart Hall and Tony Jefferson (eds), Resistance Through Rituals: Youth Subcultures in Post-War Britain (London, 1976).

${ }^{22}$ Compare Crossley or Muggleton's analysis with, for example, Pete Dale, Anyone Can Do It: Empowerment, Tradition and the Punk Underground (Aldershot, 2012).

${ }^{23}$ Simon Reynolds, Rip it Up and Start Again: Post-Punk, 1978-84 (London, 2005); Jon Savage, England's Dreaming: Sex Pistols and Punk Rock (London, 1991); David Wilkinson, Post-Punk, Politics and Pleasure in
} 
Robinson and others has rooted the inter-relationship between punk, riot grrrl and feminism in its historical context, while Kirsty Lohman has traced the transformation of Dutch punk via a combination of sociological and historical analysis. ${ }^{24}$ Further afield, as it were, Ryan Moore and Cyrus Shahan have respectively produced historically-aware analyses of American and German punk's political relevance. ${ }^{25}$

More needs to be done. Our intention here is to demonstrate that punk cultures engaged with politics and that such engagement should be understood in its historical, socio-economic and geographical context. Moreover, we propose that comparative analysis allows for better understanding of how the politics of punk and punk-related cultures developed in different ways across different spaces/places even as shared cultural and aesthetic affinities remained. We have neither the space nor the inclination to enter into debate as to 'what is punk'. Suffice to say both Crass and Rondos understood themselves to be informed by and part of punk's cultural impetus. Both, too, related their cultural practice to political expression, exploring questions of anarchy and autonomy as they sought to find a way out of the twentieth century.

\section{Crass: The system might get you but it won't get me ...}

Crass first came to prominence as 1978 turned to 1979, gaining attention around the release of their debut EP, The Feeding of the Five Thousand. ${ }^{26}$ By this time, the band had

Britain (Basingstoke, 2016); Matthew Worley, No Future: Punk, Politics and British Youth Culture, 1976-84 (Cambridge, 2017).

${ }^{24}$ Laura Cofield and Lucy Robinson, "The Opposite of the Band": Fangrrrling, Feminism and Sexual Dissidence', Textual Practice, 30, no. 6 (2016), 1071-88; Kirsty Lohman, The Connected Lives of Dutch Punks: Contesting Subcultural Boundaries (Basingstoke, 2017).

${ }^{25}$ Ryan Moore, Sells Like Teen Spirit: Music, Youth Culture and Social Crisis (New York, 2010); Cyrus Shahan, Punk Rock and German Crisis: Adaptation and Resistance after 1977 (New York, 2013).

${ }^{26}$ Crass, The Feeding of the Five Thousand (Small Wonder, 1978). The record was actually issued in early 1979 
evolved from their rather ramshackle beginnings to become a more serious proposition, presenting themselves as an alternative to what they perceived as punk's co-option by the music business. Writing in October 1977 for the first edition of Gee Vaucher's International Anthem, a 'nihilist newspaper for the living' that helped connect the countercultural publications of the late 1960s to punk's burgeoning fanzine culture, Rimbaud outlined Crass' position:

[Within] six months [punk] was bought up, the capitalist counterrevolutionaries had killed with cash. Punk shot from being a movement for change to the biggest media bonanza since "hippie" [...] another cheap product for the middle-class consumer [...] If the first-wave punkers [...] have sold out and become property in some wanked out economic system, it's up to the second wave to fight a hard battle. ${ }^{27}$

Accordingly, Crass embraced punk's emergent tendency for independent production, seeking wherever possible to circumnavigate the mechanisms of the music industry and media. Having released The Feeding of the Five Thousand on Small Wonder, they set up their own record label, Crass Records, and adopted a 'pay no more than ...' pricing policy. Opportunities were given to like-minded bands to release their music, be it as one-off singles, albums or via the Bullshit Detector compilation series that showcased punk claims that 'anyone can do it'. Live, Crass increasingly performed beyond the recognised gig circuit,

having run into trouble when the foreman at an Irish pressing plant objected to the blasphemous content of the opening track ('Asylum').

27 Penny Rimbaud, 'Crass at the Roxy', International Anthem, no. 1 (1977), pp. 5-10. 
preferring community centres and scout huts in out-of-the-way places to established venues. They also shunned the mainstream music press (Melody Maker, NME, Sounds), meaning fanzines became a key means of communication. Subsequently, a number of aspiring young writers sent letters or made the journey to Dial House, sitting with Rimbaud and others around the kitchen table, smoking cigarettes, drinking tea, discussing life, the system and the politics of punk.

Alongside Poison Girls, a staunchly feminist punk band from Brighton with an anarchist pedigree, Crass had by this time too begun to forge a relatively comprehensive socio-political critique that they articulated across various records, pamphlets, posters, communiqués, films, fanzine pieces and fanzines. ${ }^{28}$ Christ - The Album (1982) even came replete with a booklet that featured Rimbaud's 'The Last of the Hippies', an extended essay intersecting the story of free-festival organiser Wally Hope's (Phil Russell) death with diatribes against punk factionalism and a bleakly oppressive history of post-war geopolitics. ${ }^{29}$ Throughout Crass' oeuvre, the state was presented as an apparatus of repression that wielded power in defence of vested interests (politicians, the owners of capital). Its forces - the police, government, military and law courts - provided the tools by which all vestige of opposition was managed and suppressed. The media, of course, served as an opiate for the masses and a means of indoctrination; religion harboured the archaic root of moral oppression. Socially, the family existed as a site of conditioning through which gender roles and hegemonic values were imposed and then reinforced via education. The

\footnotetext{
${ }^{28}$ Cross, 'The Hippies Now Wear Black', 25-44; idem, "There is No Authority But Yourself": The Individual and the Collective in British Anarcho-Punk', Music and Politics, 4, no. 2 (2010). As well as Vaucher's International Anthem, Andy Palmer produced two issues of The Eklektik. For Poison Girls, see Rich Cross, "'Take the Toys from the Boys": Gender, Generation and the Anarchist Intent in the Work of Poison Girls', Punk \& Post-Punk, 3, no. 2 (2015), 117-45; 'Poison Girls', Anarchy, no. 34, 1981, pp. 5-11.

${ }^{29}$ Penny Rimbaud, 'The Last of the Hippies - An Hysterical Romance', in Crass, A Series of Shock Slogans and Mindless Token Tantrums (London, 1982).
} 
maintenance of power was serviced through consumerism, the exploitation of science and a war machine that projected the threat of nuclear holocaust. 'The nature of your oppression', Rimbaud insisted, 'is the aesthetic of my anarchy'. ${ }^{30}$

From such a reading, Crass adopted anarchism as an expression of individual will and a mode of creative resistance. Beyond running their own self-sustained lives from Dial House, the band lent support to the Campaign for Nuclear Disarmament (CND), carried out graffiti campaigns, helped establish the London Autonomy Centre, contributed to the 'Stop the City' demonstrations of 1983-84 and preformed benefit gigs for striking miners. In 1982 they produced two records condemning the Falklands War that led to questions in parliament and threats of prosecution. A year later, the circulation of a hoax-tape pertaining to a conversation on military brinkmanship between Margaret Thatcher and Ronald Reagan sparked a government inquiry. ${ }^{31}$ More generally, Crass presented their anarchism as a byway between the dualities of organised power-politics, disavowing the binaries of left and right and the cold war paradigm of east versus west. Essentialist readings of class, race, gender and sexuality were dismissed. ${ }^{32}$ If individuals were 'moulded and structured from birth', as Pete Wright insisted, then Crass' objective was to 'get people to question things instead of just accepting everything that comes along' ${ }^{33}$

Not surprisingly, Crass' ideas were soon picked over and discussed. ${ }^{34}$ Their inclusion in fanzines extended beyond the usual potted histories, with interviews running through several pages. The first of these, by Tony D [Tony Drayton] for Ripped \& Torn, set the tone.

\footnotetext{
30 Penny Rimbaud, 'The Pig's Head Controversy: The Aesthetics of Anarchy', International Anthem, no. 1 (1977), pp. 13-14.

${ }^{31}$ National Archives, PREM 19/1380, 'Forged Recording ...' (1983-84).

32 'Crass', Antigen, no. 1 (1982), pp. 11-13 (the interview took place in January 1981).

33 'Crass', In the City, no. 10 (1979), pp. 21-2.

34 There is not space here to discuss the music press' largely negative response to Crass. See, for example, Dave McCullough's think-piece on Crass in Sounds, 2 February 1982, p. 12.
} 
Taking place in a Dial House room 'lined with literally hundreds and hundreds of books, ranging from DIY to Marilyn Monroe to "Hitler's Children" (Baader-Meinhof) to Andy Warhol to RD Laing', D defined Crass as 'anarchy in action'. The band served as 'an introduction to all sorts of possibilities', Rimbaud concurred, with the transcribed conversation running from Auschwitz and the H-Blocks in Northern Ireland onto the motivations behind Crass' music and lyrics. 'As a group we don't offer answers out to people [...] The most you can do is pose problems and let people come up with their [own] answers' ${ }^{35}$

Quite what Crass' anarchism entailed was an early bone of contention. The band were asked to explain their ideas, responding to such questions as: 'You say you can't talk about a state of anarchy occurring because it exists already on a personal level, but surely it can't exist fully on a personal level when you're still surrounded by the system? ${ }^{\prime 36}$ The band's replies were fairly consistent, relating anarchy back to personal responsibly and living beyond the forces of external control. ${ }^{37}$ 'We're anarchists in thought', Vaucher suggested in one early interview, keen not to align Crass to any pre-existing theory or model. 'We're talking about ourselves and our relationship with other people', Andy Palmer added. 'But when you start trying to classify us, well that's exactly what we're trying to get away from. We are people [...] trying to relate to other people as people, and trying to get them to see themselves as people rather than as part of a mass' ${ }^{38}$ Likewise, in an interview with Simon Dwyer's Rapid Eye Movement, Rimbaud stated: 'I don't bear with all this "syndicated Anarchy" shit. Socialists claiming to be anarchists [...] Anarchy is thinking for yourself [...] We

\footnotetext{
35 'An Introduction to Crass', Ripped \& Torn, no. 16 (1979), pp. 10-11.

36 'Crass', Intensive Care, no. 2 (1980), pp. 24-7. See the interview in Pigs for Slaughter, pilot issue (1981), pp. 6-9.

37 'Crass', No More Than That (February 1981), pp. 9-11.

38 'Crass', In the City, pp. 21-2.
} 
don't want any revolution. We just want to live our lives the way we want to'. ${ }^{39}$

Rich Cross has suggested that such ideas placed Crass nearer to the individualist anarchism of Max Stirner (or William Godwin) than the class-informed collectivism of Mikhail Bakunin (whose ideas influenced punks such as Rondos). ${ }^{40}$ Rimbaud also found occasion to quote the Italian anarchist Errico Malatesta to reinforce the notion of anarchism liberating all humanity rather than a single class. ${ }^{41}$ In truth, it is difficult to locate Crass' ideas firmly within any anarchist tradition. As a collective of individuals, they each brought different influences to the band's praxis, working through issues together in a way that perhaps inevitably stoked personal and political animosities over time. The group, generally at least, appeared uninterested in ideological distinctions (other than to deny them): their anarchism was presented as self-taught, drawing from a range of ideas and practices - a DIY anarchism for a DIY culture. Notoriously, if somewhat incredulously, Rimbaud stated in 1986 that, 'at the time', Crass would have more likely thought Bakunin a brand of vodka, a statement that at best reveals the shelves of Dial House to have been heaving beneath the weight of beats, visionary poets, anti-psychiatrists and existentialists as much as they were classical anarchist tomes. ${ }^{42}$

Pacifism was the other 'sticky, gluey word' that defined Crass' political position, embodied in their slogan of 'Anarchy, Peace and Freedom'. ${ }^{43}$ Suggestions that the word suffered from hippie-connotations were given short-shrift; Rimbaud had no problem with

\footnotetext{
39 Untitled Crass interview, Rapid Eye Movement, no. 3 (1980), p. 27.

${ }^{40}$ Cross, 'There is No Authority', pp. 8-11. For anyone keen to locate aspects of Crass' thought into the anarchist tradition, the best place to start would be George Woodcock, Anarchism: A History of Libertarian Ideas and Movements (London, 1986 edition).

${ }^{41}$ Rimbaud, 'The Last of the Hippies', p. 5.

42 'In Which Crass Voluntarily Blow Their Own', sleevenotes to Crass, Best Before 1984 (Crass Records, 1986). For analysis, see Jim Donaghey, 'Bakunin Brand Vodka: An Exploration into Anarchist-Punk and PunkAnarchism', Anarchist Developments in Cultural Studies, no. 1 (2013), 138-70.

${ }^{43}$ Rapid Eye Movement, pp. 24-31.
} 
such countercultural continuums and made clear that 'pacifism never meant being passive. It's just a general term meaning don't look for answers to your problems in violence'. ${ }^{44}$ As a result, young Crass advocates such as Graham Burnett (New Crimes), Mike Diboll (Toxic Graffitti) and Lee Gibson (Anathema) were soon moving on from dissecting 'systems of oppression' to debating pacifism, anti-militarism and anarchism in their own terms. Political Asylum, schoolboy punks from Stirling, even adapted a Steve Ignorant poem, 'Passive Fist', to become part of their early set. ${ }^{45}$ Simultaneously, the strategies of the anti-war movement and CND - revived in the context of heightened cold war tensions - were unpicked and critiqued, both in articles and interviews. ${ }^{46}$

Crass' politics were influential. By the early 1980s, their ideas, aesthetics and approach were reflected in countless bands and fanzines formed across the country. Even so, aspects of Crass' worldview were seized upon and challenged. With regard to pacifism, a growing number of punk-informed anarchists began to advocate a more overtly combative politics of direct action. Conflict, who worked closely with Crass and later recruited Steve Ignorant on shared vocals, were never minded to avoid confrontation wherever it was deemed necessary. They, along with bands such as The Apostles, sought to ferment an 'ungovernable force', transforming protest into resistance. Coming from Eltham in southeast London, Conflict also retained class-affinities that found expression across certain strands of anarcho-politics, eventually coming to fruition in the guise of Class War. ${ }^{47}$

\footnotetext{
44 Ibid; Crass Statement in Kill Your Pet Puppy, no. 2 (1980), pp. 16-17; 'Crass Interview', A System Partly Revealed, no. 2 (1982), pp. 6-8.

45 Political Asylum, first demo tape (1983), on Winter (Passing Bells, 2004). The poem had been printed in the fanzine Suburban Revolt, 2 (1979), p. 9 and on the back of the flyer handed out by Crass and Poison Girls following the cancellation of a gig planned to take place at Conway Hall in November 1979. My thanks go to Nic Bullen and Chris Low for digging up this reference.

${ }^{46} \mathrm{See}$, for example, the two issues of Anathema produced by Lee Gibson in 1982.

${ }^{47}$ See fanzines as Pigs for Slaughter and Scum, both of which had links to London's Autonomy Centre.
} 
Equally, Crass' scathing attitude towards Christianity was queried. Release of The Feeding of the Five Thousand had been delayed due to objections from the pressing plant's foreman as to the blasphemous content of the opening track, a feminist critique - 'Asylum' - that depicted Christ on the cross as a 'mast of oppression' and religion as a harbinger of war. ${ }^{48}$ In response, In the City took the band to task, questioning the vitriol of 'Asylum' while pushing Rimbaud to explain his rationale for demythologising the moral imperatives of religious power; that is, 'to rid people of the guilt they've been forced to carry through other people's prejudice'. 'What we're saying', Pete Wright added, 'is that Christ's existence is now used to fortify and justify and is the reason for a whole number of actions [...] with nothing to do with Christianity as a religion. It's just a system for allowing actions that are convenient, $y^{\prime}$ know wars are fought on religious grounds, of which there can be no justification.' 49 Correspondingly, 'Reality Asylum' may be read as a feminist critique of Christianity: womanhood defiled by a patriarchal theology of 'cockfear /cuntfear / womanfear'. ${ }^{50}$

As this suggests, some fanzine writers visited Dial House more in suspicion than conviction. Vague, for example, came to Crass from a critical perspective, publishing a probing interview with the group and, later, a fairly damning overview of the 'anarcho' culture that emerged into the $1980 \mathrm{~s}^{51}$ 'I found Crass sincere and committed', Tom Vague noted, but those inspired by them were deemed to be 'weak distorted facades' surrounded by 'predictably pessimistic and unimaginative banners, sprayed with political slogans and

\footnotetext{
${ }^{48}$ Graham Lock, 'Crass By Name, Cross By Nature', NME, 20 January 1979, p. 16. The song/poem was removed and replaced by two minutes silence entitled 'The Sound of Free Speech'. It was later released as the 'Reality Asylum' single o Crass Records in 1979.

49 'Crass', In the City, pp. 21-2; 'Religion and Crass', Aftermath, no. 5 (1980), p. 5.

50 'Reality Asylum', lyrics reproduced in Crass, Love Songs (Hebden Bridge 2004).

${ }^{51}$ Tom Vague, 'Crass', ZigZag, no. 122 (1982), pp. 38-9, also published Vague, no. 11 (1981).
} 
[playing] music [that] is still that tired old Punk Rock ' $n$ ' Roll' ${ }^{52}$ From Norwich, Antigen also published a feature that read more like an inquisition than an interview, wondering if Crass would ever sell out and suggesting - as became a common critique - that the band were forging some kind of cult. ${ }^{53}$

By 1984, in the wake of the Falklands War and on the cusp of the miners' strike, Crass were fielding questions as to 'the politics of depression' and how best to confront or resist the socio-political changes occasioned by Thatcherism. ${ }^{54}$ The 'anarcho-punk' culture they helped forge had continued to broaden, extending to questions of animal liberation and further exploring the (anarcho-) feminist politics of Poison Girls. To pick up one of the many anarcho-zines of the early 1980s, cut and pasted under such names as Acts of Defiance, Enigma, Fack, Fight Back and Re-Action, is to read essays on Ireland, sexism, education, nuclear power, religion and vivisection. Alongside them, collages of missiles, police and newspaper cuttings abound, with links to other 'zines, campaign groups, bookshops and independent labels providing glimpse of the networks that sustained a recognisably punk-informed counterculture. To be sure, the spaces that enabled such activity began to narrow over the 1980s-90s, squeezed by legislative measures and broader socio-cultural changes. In the meantime, punk's anarchist rhetoric found intellectual stimulation in the DIY-practices facilitated by the Sex Pistols' cultural challenge and the ideas proffered by bands such as Crass.

\footnotetext{
52 Tom Vague, 'Those Not So Loveable Spikeytops', Vague, 14 (1983), p. 29.

53 'Crass', Antigen, pp. 11-13.

54 'Crass', Mucilage, no. 2 (1985), pp. 12-13 and 18-19.
} 


\section{Rondos: Which side will you be on?}

Rondos' approach bore both similarities and differences to Crass. Their first gig, held on 31 March 1978, came as the result of an invitation made by their art school teacher before the band had even formed. A set of mostly UK punk cover versions was quickly learnt and performed, before the rest of 1978 was given over to writing original songs and establishing connections with Dutch punks in Rotterdam and beyond. By the end of the year, Rondos had played a further 15 gigs, culminating in a show at Amsterdam's principal punk venue, Paradiso, on 14 December 1978.

Rondos were initially motivated by punk's artistic potential. The aesthetics of punk, with its dada and situationist influences, attracted their art school sensibilities; but, as Crass too realised, punk further offered a process to combine artistic form with political content. Moreover, just as Crass recognised continuities between the 1960s/70s counterculture and punk, so Rondos built on similar foundations in The Netherlands, meshing art and politics in often innovative and confrontational ways. Indeed, KK Dubio's creative endeavours had long drawn on its members' left-wing activities, with at least one associate belonging to a Maoist group in the mid-1970s. ${ }^{55}$ More broadly, The Netherlands' artistic and cultural milieus had a history of engaging with leftist or anarchist politics. The Provos, for example, emerged in Amsterdam in the 1960s, combining anarchist activities with spectacular 'provocations' to rile the police, authorities and monarchy. ${ }^{56}$ With regard to Rondos, their cultural politics were perhaps best expressed on 'A Black \& White Statement', the song that opened their Red Attack LP and featured on the subsequent Which Side Will You Be On? EP. Effectively

\footnotetext{
55 Kirsty Lohman, 'Dutch Punk with Eastern Connections: Mapping Cultural Flows between East and West Europe', Punk \& Post-Punk, 2, no. 2 (2013), 147-163.

${ }^{56}$ Richard Kempton, Provo: Amsterdam's Anarchist Revolt (New York, 2007).
} 
presented as a manifesto, it set out the band's position in blunt terms: 'no establishment's art / no deadman's heart / no bourgeois illustrations / no ruling class frustrations // but art out on the street / a new heartbeat / a new art passion / class war aggression'. ${ }^{57}$

Like Crass, Rondos' creativity was a collective endeavour. There was, however, a notable difference as to how this materialised. The band's base at the Huize Schoonderloo, a building designated for demolition, had been secured in arrangement with Rotterdam's city council. Rotterdam still bore the scars of World War Two bombing and its rebuilding was designed to be cultural as well as physical. ${ }^{58}$ As a result, it was with local government support that Rondos and KK Dubio helped cultivate Rotterdam's punk scene, through which the collective pushed for rehearsal space and venues in the city. Updates of their activities and successes in negotiating with the government were detailed in Raket.

Such a relationship between Rondos and the local authorities may seem problematic, especially given punk's oppositional discourse. Certainly, Dutch punks were more used to gaining spaces through squatting than in collaboration with government. ${ }^{59}$ Even so, punk's cultural focus allowed for a degree of establishment tolerance - even encouragement; Raket received a local government subsidy to help with its printing costs. By negotiating such opportunities, however, KK Dubio stood somewhat apart from other particularly anarchist - punks, including the makers of Koecrandt, an Amsterdam fanzine that heavily criticised Raket's financial arrangements.

More analogous to Crass' approach was Rondos relationship with and

\footnotetext{
${ }^{57}$ Rondos, 'A Black \& White Statement', Red Attack (King Kong, 1980) and Which Side Will You Be On? (King Kong, 1980).

${ }^{58}$ Ron Blom and Bart Van der Steen, 'Een banier waar geen smet op rust': De geschiedenis van het trotskisme in Nederland, 1938 - heden (Soesterberg, 2015).

${ }^{59}$ Lohman, The Connected Lives of Dutch Punks (forthcoming).
} 
encouragement of other bands. They released two split EPs in 1979 (the first with Railbirds; the second with Terminal City, Railbirds and Bunker) and formed a Red Rock Collective alongside Rode Wig, Sovjets and Tandstickörshocks. This, in turn, was understood as a collective response to capitalism:

We try to have as little to do with the capitalist game as possible, for us that means: no record companies - no expensive audio equipment bought on credit and no managers. We prefer to do everything ourselves, together. That's why we have also, together with others, set up the Red Rock Collective [...] All equipment is shared. ${ }^{60}$

Comprising communist and anarchist bands, all with different musical styles, the Red Rock Collective foregrounded political messages. ${ }^{61}$

Rondos use of media beyond music was also resonant of Crass. With others from KK Dubio, the band produced Raket and, from April 1979, Huize Schoonderloo provided base for a publishing house and distribution. Raket was positioned as the 'mouthpiece' for Rotterdam's - and, later, as the fanzine's reach grew, The Netherlands' - punk scene. ${ }^{62}$ It advertised new and old bands; flagged upcoming gigs and record releases; printed letters and essays dealing with a variety of political issues. Some of the content was created by members of the collective, but Raket thrived on submissions received from across the wider Dutch punk scene. The fanzine also maintained a policy of printing everything it received, up

\footnotetext{
${ }^{60}$ Rondos, 'Rondos Over Kommunisme', Raket, no. 10 (March 1980), n.p.

61 'Red Rock', Raket, no. 7 (December 1979), n.p.

62 This was written on the cover of every issue of Raket.
} 
to and including some right-wing propaganda pieces with the proviso: '[We] do not want to apply censorship to a single thing so you can read this letter and make up your own mind what you think about fascism'. ${ }^{63}$ By so doing, the collective sought to foster debate and allow for critical reflections on punk's politics. In a complementary reversal of Crass' submitting interviews and material to fanzines, Rondos opened up their own publication to others.

From within the collective, Rondos were determined to spread knowledge of their own politics, producing records that stated far stronger political positions than revealed in Raket. The band's approach was deliberately provocative, with sharp-shouty vocals overlaying mainly ornamental guitar work and pounding bass and drums. (Their first gig featured three bassists.) Musically, they recalled British bands such as The Mekons and Gang of Four - groups, incidentally, who also worked collectively and recognised in punk a politically potent fusion of form and content. Lyrically, Rondos engaged with war ('Soldiers', 'Royal Marines', 'B-52 Pilot'), alienation, capitalism and consumption ('City Boy', 'Syphilips', 'Tools'), religion ('Jesus Crisis'), vivisection ('Vivisection') and fascism ('A Waltz') - all subjects that corresponded with the focus of British anarcho-punk. Textually, meanwhile, Cold War imagery - including Vietnam, nuclear war and the motifs of East and West coalesced with the spectre of World War Two and the Holocaust. The threat of authoritarianism served as a connecting thread through their whistle-stop tour of twentiethcentury history. Notably absent, however, were questions of gender. Unlike Crass, class overrode all other understandings of inequality.

\footnotetext{
63 This disclaimer was published in Raket, 8 (January 1980), n.p. For more details of Raket's approach to - and the consequences of - their no-censorship policy, see Kirsty Lohman, 'Punks Against Censorship: Negotiating Acceptable Politics in Dutch Fanzine Raket', in Subcultures Network, Ripped, Torn and Cut: Pop, Politics and Punk Fanzines from 1976 (Manchester, 2018, forthcoming).
} 
As with Crass' relationship to anarchism, quite what Rondos' communism entailed remained a site of contention. 'One Solution', which the band never recorded, staked out their goal as a (communist) revolution: 'rich are getting richer / poor are getting poorer / there is one solution / start a revolution'. This, in turn, was expanded upon in essays for Raket. Therein, some sympathy was shown for the 'guerrilla' actions of the West German Rote Armee Fraktion (Red Army Faction), although Rondos more typically advocated a slower, mass-led revolution. ${ }^{64}$ Thus, in one five-page essay - 'Rondos on Communism' - the band appeared to distance themselves from orthodox Leninism: 'We believe that seizing power is only possible if the majority of the people support it. It can therefore never happen through a small group or party'. ${ }^{65}$ They explicitly, and regularly, distanced themselves from established political organisations, seeking instead a DIY form of 'organised' politics. Punks were urged to build a movement; to educate each other and the rest of the public about the ills of capitalism. All (anti-capitalist) punks, be they anarchist or communist, were to work together against their common enemies: fascists and capitalists. Punk, after all, was synonymous with 'resistance' in the Dutch context, where the overriding slogan 'punk is verzet' ('punk is resistance)' remains pertinent today. ${ }^{66}$

Despite this, the band often resisted being labelled 'communist' or 'Maoist'. While contributors to Raket were invited to discuss the finer points of anarchism, Rondos themselves wrote essays and lyrics navigating the contours communism. 'Russians Are Coming', from their first single, asserted the band's anti-Soviet position by critiquing Russian

\footnotetext{
${ }^{64}$ Rondos, 'Rondos Over Kommunisme', n.p.

65 ibid.

${ }^{66}$ Lohman, The Connected Lives of Dutch Punks (forthcoming).
} 
militarism and interventionism, sentiments that were regularly repeated in Raket. ${ }^{67}$ It was clear, too, that Rondos wished to distance themselves from the stereotypes of 'student leftists' or 'champagne socialists'. On the unrecorded 'Money Enough to Buy the Complete Works of Marx \& Engels' the band took aim and fired: 'you're the left-wing elite / the communist superstars / scared of working people / and kissing Lenin's arse'. ${ }^{68}$ As for Chinese communism, Rondos' position was less-clearly articulated, with statements of respect for the Chinese government being immediately followed by more cautious comments acknowledging China's mistakes: 'Rondos in no way promote China. We have neither songs nor essays about it. People should research for themselves what can be learnt from China. We see a lot of positive things in China [...] We think we can learn from China - from the good and the bad. ${ }^{\prime 69}$ As a result, it should be of little surprise that the 'Maoist' label stuck to Rondos, despite the band's protests and their fumbling towards what appeared to be a punk-informed version of anarcho-syndicalism. Issues of Raket regularly featured artworks drawing from the slogans 'Punx Unite' and 'Red \& Black: Strike Back'.

Rondos split in 1980, winding down Raket the fanzine but continuing Raket the publishing house through until 1987. As should be clear, they shared much in common with Crass and it should be no surprise that the two bands made contact with one another. Once contact was made, however, political differences soon emerged, revealing much about how punk's politics were contested and how perennial debates as to mechanisms of social change continued to find expression across evolving cultural contexts.

\footnotetext{
${ }^{67}$ Rondos, 'Rondos Over Kommunisme', n.p.

68 Rondos, 'Money Enough to Buy the Complete Works of Marx \& Engels', in Rondos, A Black \& White Statement (King Kong, 2009).

${ }^{69}$ Rondos, 'Antwoord aan: Henno Eggenkamp', n.p.
} 


\section{Peace dilemma}

Both Crass and Rondos recognised in punk a cultural process of critical engagement. Punk provided them with a platform to articulate political positions bound up in their creative practice. Both bands were overtly political. They engaged with questions of geo-politics and personal politics. Simultaneously, both proved wary of political labels or ideologies that confined or defined their respective positions. Their ideas and approaches drew from a range of influences, including the countercultural formations that emerged through the 1960s. To this end, Crass and Rondos gave cultural expression to on-going realignments across radical and/or leftist politics in the late twentieth century; realignments that saw intersections through class, race, sexuality and gender; the emergence of a New Left and the dilution of 'old' fixations on economics and the (white) male worker; the onset of postmodernism, crises of social democracy and a politics of consumption; student protests, peace movements and the 'cultural turn' ${ }^{70}$

The implications of such socio-political transformations are still being played out into the twenty-first century, refracted in turn through such prevailing forces as neoliberalism, conservatism and globalisation. Not surprisingly, they have also given rise to competing priorities and approaches, sometimes cutting into and sometimes galvanising forces of social, cultural and political change. With regard to Crass and Rondos, this became clear in the wake of their Conway Hall gig with Poison Girls on 8 September 1978. The gig itself was

\footnotetext{
${ }^{70}$ Stephen Brooke, Sexual Politics: Sexuality, Family Planning and the British Left from the 1880s to the Present Day (Oxford, 2011); Jodi Burkett, Constructing Post-Imperial Britain: Britishness, 'Race' and the Radical Left in the 1960s (Basingstoke, 2013); Celia Hughes, Young Lives on the Left: Sixties Activism and the Liberation of the Self (Manchester, 2016); Michael Kenny, The First New Left (London, 1995); Lucy Robinson, Gay Men and the Left in Post-War Britain: How the Personal Got Political (Manchester 2007); Natalie Thomlinson, Race and Ethnicity in the Women's Movement in England, 1968-93 (Basingstoke, 2016); Matthew Worley, 'Marx-LeninRotten-Strummer: British Marxism and Youth Culture in the 1970s', Contemporary British History, 30, no. 4 (2016), 505-21.
} 
a benefit for six anarchists arrested in the summer of 1978 for conspiring to 'cause explosions with persons unknown' ${ }^{71}$ But it was further marked by a violent political clash between anti-fascist activists, some of whom were attached to the Socialist Workers Party (SWP), and young skinheads mobilised by the neo-Nazi British Movement (BM). Accounts vary dramatically, but all agree it was a bloody night, with low-level bullying and intimidation transforming into vicious confrontation before Crass even made it to the stage. $^{72}$

Leaving aside the implications of the Conway Hall gig for the political organisations and tendencies involved, the episode exposed fissures running between Crass and Rondos' respective politics. Most obviously, questions of political violence and the validity of pacifism came to the fore, paving the way for a protracted debate that spread beyond the three bands (including Poison Girls) into fanzines and political periodicals. Where, previously, amidst a Rondos visit to Dial House, talk had been of shared tours and split records, relations subsequently broke down as discussion turned to how best engage with fascism and the limitations of pacifism.

Violence was nothing new at gigs in the 1970s. Punch-ups and set-tos were common, relating more often than not to territorial claims or teenage style wars played out in spectacular excess. But the 'bovver' could sometimes be political, especially once punk emerged to open a contested cultural space that found appeal on both the left and the

\footnotetext{
71 Persons Unknown, Persons Unknown (London, 1979); Persons Unknown, directed by Gordon Carr (1980); David Clark, '18 Months in the Waiting', The Leveller, October 1979, pp. 7-8. The six arrested were Ronan Bennett, Stewart Carr, Trevor Dawton, Dafydd Ladd, Iris Mills and Vince Stevenson.

72 'Crass - "Heavy Mob" Invade', The Leveller, October 1979, p. 6; Rimbaud, Shibboleth, pp. 118-24; Martin Lux, Anti-Fascist (London, 2006), pp. 89-95; Sean Birchall, Beating the Fascists: The Untold Story of Anti-Fascist Action (London, 2010), pp. 41-3; Rondos, A Black \& White Statement, pp. 64-7.
} 
right. ${ }^{73}$ In its musical style and aesthetic, punk signalled angry disaffection. Early punk also played with political symbols, most notoriously the swastika. Subsequently, both the National Front (NF) and the BM targeted youthful recruits, to which the left responded with RAR and the Anti-Nazi League (ANL). By 1979, clashes between left and right had become an all-too-regular by-product of punk's cultural intervention and were replicated in many other contexts.

In the wake of the trouble at Conway Hall, both Crass and Poison Girls issued statements - sent also to fanzines and sections of the radical press - condemning the politics of force and distancing themselves from either side of the political divide. ${ }^{74} \mathrm{~A}$ joint pamphlet was printed and, in 1980, a joint single - 'Bloody Revolutions' b/w 'Persons Unknown' - was released to raise money for a London anarchy centre, actions designed to reassert the bands' belief in the 'negation of force' ${ }^{75}$ Thus, Poison Girls accused both the SWP and BM of supporting the 'the system of gang warfare': 'right wing, left wing, people with old and new ambitions for power and control'. ${ }^{76}$ Rimbaud, meanwhile, saw political violence only as a means of asserting domination. In fact, Rimbaud laid the blame for Conway Hall on the SWP, accusing the 'organised left' of transforming punk from 'OUR playground' to 'THEIR battlefield'. Not only did he criticise RAR for building 'a platform for political approval' that simultaneously closed down dissenting voices, but he conflated such initiatives with the far-right's Rock Against Communism (RAC) campaign. 'Why shouldn't there be RAC gigs? Is the slaughter of thousands by communist idealists in Russia and China

\footnotetext{
${ }^{73}$ Worley, 'Shot by Both Sides', 333-54.

${ }^{74}$ Crass, 'Following the 8/9/79 Conway Hall Agro', Toxic Grafitty, no. 4 (1979), pp. 7-8; Crass, 'Statement', Kill Your Pet Puppy, no. 1 (1979), p 13-15.

75 Crass and Poison Girls, Untitled Pamphlet, October 1979; Crass and Poison Girls, 'Bloody Revolutions' b/w 'Persons Unknown' (Crass Records, 1980).

76 'Poison Girls Say', The Leveller, October 1979, p. 6
} 
any different from the slaughter of thousands in Hitler's Germany?'77 'As an anarchist', Rimbaud insisted, 'I stand against all authority' and for the 'right of the individual'. ${ }^{78}$

Crass' position, as articulated by Rimbaud, proved controversial, triggering fanzine debate and some discussion in The Leveller, a non-aligned radical paper of the left. ${ }^{79}$ One contributor to Kill Your Pet Puppy accused Crass of 'encouraging people to passively accept violence' and insisted anarchists must agree to class war and fight back. ${ }^{80}$ In reply, Rimbaud issued a short essay through the same fanzine outlining his belief in anarchy as 'the politics of the free mind' and pacifism as a 'stand against organised militarianism [sic]'. ${ }^{81}$

Rondos understood things rather differently. Initially, they remained quiet on the matter, having left the UK confident that future projects with Crass were still in the works. The September 1979 issue of Raket even contained an announcement that Crass would soon be coming to The Netherlands to play gigs with Rondos. By November's issue, however, things had evidently changed: Crass had phoned Rondos to say they wouldn't be coming after all. 'Exactly why, is not clear, but they said they will write to us [to explain]' ${ }^{82} \mathrm{~A}$ letter duly arrived, the details of which found their way into December's Raket alongside a brief description of the Conway Hall gig for the benefit of Dutch punks unaware of what had happened. The tour was off, Raket quoted Crass as saying, 'because the Rondos' ideas are not $100 \%$ [in line with] those of Crass and that would [...] confuse the public' ${ }^{83}$

Rondos' understanding of Crass' critique honed in on two issues. First, in relation to

\footnotetext{
${ }^{77}$ Crass, 'Following the 8/9/79 Conway Hall Agro', pp. 7-8.

${ }^{78}$ Kill Your Pet Puppy, no. 2, pp. 16-17.

79 David Brazil, 'Spittin' Hate at the Future of Rock ' $n$ ' roll', The Leveller, October 1979, pp. 18-19; idem, 'Gatecrashers', The Leveller, November 1979, pp. 26-7; Intensive Care, nos. 1 and 2 (1980); Kill Your Pet Puppy, nos. 1 and 2 (1980).

${ }^{80}$ Buenaventura Makhno, 'Peaceful Pro-Crass-tination', Kill Your Pet Puppy, no. 1 (1980), p. 16.

${ }^{81}$ Kill Your Pet Puppy, no. 1, pp. 16-17.

82 'Crass Komt Niet Naar Nederland!', Raket, no. 6 (November 1979), n.p.

${ }^{83}$ Rondos, 'Waarom Komt Crass Niet Naar Nederland??', Raket, no. 7 (December 1979), n.p.
} 
pacifism, the band insisted: 'We believe that sometimes it might be necessary to use violence, for example, in order to counter 20 fascists beating up 600 punks such as at Crass' gigs' ${ }^{84}$ Even more seriously, perhaps, Rondos accused Crass of putting the (punk) public at physical risk by combining a pacifist philosophy with an aggressive live performance that effectively served as a catalyst for violence - especially when the band refused to play venues that employed security. ${ }^{85}$ By not engaging with fascism either theoretically or physically, Rondos argued, and by adopting pacifism as a response to oppressive force, Crass were ultimately more responsible for the violence than either the BM or SWP.

Second, Rondos responded to Crass' dismissal of communism and political organisation. An essay also published in issue 7 of Raket, titled 'Rondos on Anarchism and Communism', outlined the band's position. Parallels between communism and anarchism were drawn, primarily the pursuit of revolutionary change and an end to state control, while common cause was asserted for the sake of punk unity. Nevertheless, against Rimbaud's rejection of structured political groups (and the left in particular), Rondos suggested that some basic form of organisation was necessary to achieve even an anarchist revolution. ${ }^{86}$

Initially, at least, Rondos believed their disagreement with Crass to be intellectual and therefore no threat to their working relationship. Punk was, after all, conceived by Rondos as a space to reconcile such division towards a common cause. Though plans for joint gigs had evidently fallen through, the Dutch band reasserted their friendship with Crass and committed to releasing a split single in the future. Only with the release of 'Bloody Revolutions' in 1980 did relations break wholly beyond repair, paving the way for a review

\footnotetext{
84 ibid.

85 Red Rat, 'Crass', Raket, no. 14 (November 1980), n.p. 'We believe that, in effect, the public is the victim of the fighting at Crass' gigs, and therefore [the victim] of Crass' pacifism'.

${ }^{86}$ Rondos, 'Over Anarchism en Kommunisme', Raket, no. 7 (December 1979), n.p.
} 
of the single that once more criticised Crass' pacifist response to fascism and an essay, published in the final issue of Raket (November 1980), that unpicked Crass' politics across seven pages. ${ }^{87}$ In this, a series of disagreements were outlined, comprising fourteen 'Crass and ...' sections that ranged from 'anarchism' and 'Christianity' to 'punk', 'the fan club' and 'capitalism' ${ }^{88}$

Interestingly, Rondos sought to philosophically locate the dispute. Reference was made to the ideas of Pyotr Kropotkin, Nestor Makhno and Mikhail Bakunin. Simultaneously, the ultimate objective of a worker-peasant (or, in the Dutch context, worker-farmer) revolution was reasserted; an objective, of course, that Crass did not share. To this end, Crass' anarchism was denigrated as a 'state of mind'; their 'fake pacifism' compared to the Christian doctrine of 'turning the other cheek'. In fact, Rondos saw Crass' condemnation of religion as inadequate and focused too much on the figure of Jesus rather than the wider institutions of Christianity. They even drew parallels between religious cults and the faithful following that was building around Crass. With Rondos engaged in campaigns such as Rock Against Religion, Crass effectively became an opium of the people - pacifying the revolutionary potential of the working class and thereby undermining the transformative aims of both anarchism and communism. Rondos, by contrast, regretted that violence was justified on occasion and, indeed, was necessary to the revolutionary struggle. ${ }^{89}$

The Dutch context is important here, primarily the experience of Nazi occupation during the Second World War. Popular discourse in The Netherlands, especially in the midtwentieth century, revolved around the notion of widespread 'heroic' resistance to

\footnotetext{
${ }^{87}$ This essay was vitriolic, however in the liner notes to $A$ Black \& White Statement (King Kong, 2009) the band admit that, with hindsight, perhaps the piece had gone a little too far.

${ }^{88}$ Red Rat, 'Crass', n.p.

89 ibid.
} 
fascism. ${ }^{90}$ By the 1970 s, however, this 'founding myth' ${ }^{91}$ - maintained by the government in an effort to unite The Netherlands' fragmented post-war society - was being challenged. Attention was drawn to the lack of deep-rooted resistance and to examples of complicity with the Nazi occupiers..$^{92}$ Consequently, the need for active resistance to the rising rightwing threat of the late 1970s was amplified. Not only did Rondos thereby imply that Crass gave tacit support to fascism (by not actively opposing it), but they also accused the British band of failing to produce sufficiently anti-fascist songs/statements. In effect, Rondos tied Crass' pacifism to the lack of effective resistance to the Holocaust.

As should be clear, the disagreements between Crass and Rondos brought a punkish twist to long-standing political debates. They also revealed conflicting understanding of punk's cultural politics. Where Rondos foresaw punk as a means of working through political differences towards some kind of commonality, their experience with Crass confirmed a wider sense of despondency as to the culture's radical potential. In Crass they saw a band 'preaching' to 'disciples' and 'excommunicating' those who did not conform, a criticism bolstered by an earlier dispute between Crass and another Dutch band, The Nitwitz. Having invited them on tour, Crass later denounced The Nitwitz as sexist and reputedly pulled the plug on their performance at Paradiso in March $1979 .{ }^{93}$ Accordingly, Rondos' 'Which side will you be on?' - a song presenting a scenario of fascist takeover - was directed at Crass: 'On the day this system falls/ On that day with our backs against the wall / [...] When they

\footnotetext{
${ }^{90}$ Pieter Lagrou, 'The Politics of Memory: Resistance as a Collective Myth in Post-War France, Belgium and the Netherlands, 1945-1965', European Review, 11, no. 4 (2003), 527-549.

${ }^{91}$ Matthijs Kronemeijer and Darren Teshima, 'A Founding Myth for the Netherlands: The Second World War and the Victimization of Dutch Jews', Humanity in Action:

http://www.humanityinaction.org/knowledgebase/293-a-founding-myth-for-the-netherlands-the-secondworld-war-and-the-victimization-of-dutch-jews [accessed 28/06/2017].

92 Jeroen Dewulf, Spirit of Resistance: Dutch Clandestine Literature During the Nazi Occupation (New York, 2010).

${ }^{93}$ Red Rat, 'Crass', n.p.
} 
protect property with guns/ [...] in times of riots and guerrilla warfare/ [...] which side will you be on ' $^{94}$ Coming from the other direction, Crass understood Rondos to be bringing just the kind of divisive politics into punk that they sought to transcend. If there hadn't been trouble at Conway Hall, Rimbaud later reflected, then 'Rondos would create it'. ${ }^{95}$ Talk of armed struggle, with quotes from Marx and Mao, pointed only to big men with tommy guns: 'just another set of bigots with their rifle-sights on me'. ${ }^{96}$ Subsequently, the Rondos' split was informed - at least in part - by concern that they exerted too much influence on the Dutch scene. They feared becoming a Rotterdam equivalent of Crass; both a central focus for a politically-informed punk culture and a scapegoat. 'We wanted to collaborate not lead', they recalled, noting how Dutch teenagers too often reproduced rather than critically engaged with their ideas. ${ }^{97}$ In any case, the copy of Raket featuring Rondos' analysis of Crass' politics was duly sent to Dial House in the hope that the English band would learn from it. Fittingly, perhaps, the text was in Dutch, leaving just the cartoons - of Crass overseeing Nazi skinheads jumping on spikey-haired punks - and symbolism (Crass' logo next to a $\$$ representing capital) for the English band to decipher. ${ }^{98}$

\section{Conclusions}

The debate that followed Crass, Poison Girls and Rondos' gig at the Conway Hall sheds light on punk's evolution beyond a primarily symbolic association with anarchy towards a more critically worked out cultural politics. That punk's political meaning - both implicit and

\footnotetext{
${ }^{94}$ Rondos, 'Which side will you be on?', Which Side Will You Be On EP (King Kong, 1980).

${ }^{95}$ Rimbaud, Shibboleth, pp. 118-19.

${ }^{96}$ Crass, 'Bloody Revolutions' (1980)

${ }^{97}$ Rondos, 'A Black \& White Statement', p. 77; Jonker, No Future Nu, n.p..

${ }^{98}$ Red Rat, 'Crass', n.p.
} 
explicit - remained contested should be clear. But Crass and Rondos provide examples of bands endeavouring to instil punk's cultural practice with political implication: to be more than 'just' music; to be more than 'just' product. By so doing they helped provoke a protracted discussion as to the relationship between culture and politics that fuelled and gave shape to punk's dissipation into the 1980s. While the two bands ultimately fell out, Crass and Rondos - initially at least - recognised a kindred spirit of creative opposition. Both sought to forge a cultural politics existing beyond organisational and aesthetic structures. Both sought to circumnavigate the commercialised culture industry, even if Rondos' less anarchistic principles allowed them to take advantage of opportunities afforded by Dutch local government. Fanzines - an underground press - served alongside records as their principal means of communication.

Such debate was notable for many reasons. Most obviously it served as an example of punk's transmission across borders; of bands and cultures connecting, collaborating and debating. Whatever Crass and Rondos' disagreements, UK-Dutch networks continued to form through the wider post-punk diaspora. ${ }^{99}$ Rondos were certainly enthused by Crass. On first hearing The Feeding of the Five Thousand, they admitted to being overwhelmed by the sound, lyrics and imagery, even adopting a uniform of suits with red politischer schutzhaftling (political prisoner) triangles akin to Crass' stark black attire. ${ }^{100}$ Crucially, however, they sought then to collaborate rather than imitate. Indeed, the cultural tendrils of British punk were not simply replicated. Iterations took their own direction, transmuting through distinct contexts and interpretation. In return, British bands such as Crass were challenged to reaffirm or adapt their praxis.

\footnotetext{
99 John Robb, Death To Trad Rock (London, 2009), pp. 145-66.

${ }^{100}$ Rondos, 'A Black \& White Statement', p. 64.
} 
More specifically, the Conway Hall gig raised questions as to anarchy, pacifism, fascism and the power structures of organised politics. It proffered different forms of political strategy. In the UK, Crass' anarchism was criticised but nevertheless provided the basis for a significant strand of oppositional politics into and beyond the 1980s. ${ }^{101}$ Even Class War, whose confrontational approach rubbed against the pacifist grain, acknowledged Crass' importance in creating an 'embryonic political movement' that 'reached punters in towns, villages and estates that no other anarchist messages could ever hope to reach' ${ }^{102}$ Anti-militarist, animal rights and anti-capitalist campaigns were all given a fillip by the involvement of young punks politicised by Crass and their descendants. ${ }^{103}$ Rondos, meanwhile, informed a Dutch punk milieu open to communist or socialist ideas and committed to organised resistance. ${ }^{104}$ Away from Amsterdam, where anarchistic tendencies were fuelled by violent squat clearances, Rondos forged networks that played benefits for striking workers, harboured refugees and combated neo-Nazis. Equally, the Rotterdambased group participated with other punks, squatters and anarchists in the riots that served as backdrop to Queen Beatrix's coronation on 30 April 1980.

Context was important. Both bands saw punk as taking up the challenge of a sixties counterculture that had fallen into disrepair; co-opted and contained by the machinations of 'the system'. ${ }^{105}$ Both recognised culture - including rock ' $n$ ' roll - to have opened up spaces and facilitated practices able to break down socially created divisions. To this extent,

\footnotetext{
${ }^{101}$ McKay, Senseless Acts of Beauty, pp. 73-102.

102 Ian Bone, Bash the Rich: True-Life Confessions of an Anarchist in the UK (Bath, 2006), p. 119.

${ }^{103}$ Rich Cross, "Stop the City Showed Another Possibility": Mobilisation and Movement in Anarcho-Punk', in Mike Dines and Matthew Worley (eds), The Aesthetic of Our Anger: Anarcho-Punk, Politics and Music (Colchester, 2016), pp. 117-56; Francis Stewart, 'This is [Not] the ALF? Anarchism, Punk Rock and Animal Advocacy', Punk and Post-Punk, 5, no.3 (2017), 227-45.

104 Lohman, The Connected Lives of Dutch Punks. Bands influenced by such an approach include Man Lifting Banner, Profound and Lärm

${ }^{105}$ Rimbaud, 'The Last of the Hippies', pp. 3-8.
} 
Crass and Rondos engaged in the 'cultural turn' that evolved over the late twentieth century, moving away from party-oriented - often class-based - politics towards new spheres of struggle and new modes of expression. To be sure, their priorities, focus and approach were not always in step. The bands' members drew from countercultural and political forebears particular to their respective experience. As a result, their disagreements shine light on the uneasy relationship that developed between leftist politics (including the New Left), protest movements and the counterculture through the later twentiethcentury. ${ }^{106}$ The dialectics of liberation were complex. While Crass sought to move beyond formal politics to unpick then reconfigure social relations in pursuit of creative fulfilment, Rondos held fast to leftist precepts even as they recognised the personal to be political. Their resort to theory and a willingness to engage physically with political opponents contrasted with Crass' attempts to circumvent the parameters of organised politics and so develop the liberatory aspirations of anarchism. Consequently, the bands' respective politics were sometimes lost in more than translation.

Ultimately, punk proved too amorphous to provide the simultaneously critical-butcoherent cultural form that both Crass and Rondos (in slightly different ways) imagined. Nevertheless, punk did signify a means to forge a culture of engagement through which political ideas could be explored, tested and expressed. By so doing, a pathway from creative expression to political activism was opened up and bound to an ethos of DIY. Bands like Crass and Rondos were conduits, facilitating communication across borders in search of

\footnotetext{
${ }^{106}$ See, for example, Jeff Nuttall, Bomb Culture (London, 1968); Sheila Rowbotham, Lynne Segal and Hilary Wainwright, Beyond the Fragments: Feminism and the Making of Socialism (London, 1979); J. D. Taylor, 'The Party's Over? The Angry Brigade, the Counterculture, and the British New Left', Historical Journal, 58, no. 3, 2015, 877-900.
} 
alternative cultures and political possibilities. 